\title{
Raising of geo ecological safety of engineering collectors: the new method of assessment of water tightness of reinforced concrete blocks with basalt plastic lining
}

\author{
Olga Lyapidevskaya ${ }^{1, *}$, Andrey Sherstnev ${ }^{1}$ \\ ${ }^{1}$ Moscow state university of civil engineering, Yaroslavskoye shosse, 26, Moscow, Russia, 129337
}

\begin{abstract}
This work presents analytics ways to estimation and assessment of water tightness of reinforced concrete blocks with basalt plastic lining for increasing geo ecological safety of engineering collectors. It is proved the advisability of application basalt plastic lining instead secondary protection of concrete with hydraulic seal. The results of estimation filtration coefficient and assessment of water tightness of basalt plastic lining of engineering collectors are represented. It is carried out comparative analysis of filtration coefficient and water tightness data of basalt plastic lining and secondary protection. The geo ecological effect is proved at the expense of application of new materials and reducing breakdown events with collectors that may lead pollution of ground and subsoil water with sewage.
\end{abstract}

\section{Assessment of water tightness of reinforced concrete blocks with basalt plastic lining and secondary protection}

The exploration of city underground space with simultaneous reservation of environment is one of priority directions for building construction development.

In this connection the problem of increasing geo ecological safety and durability of underground construction (including tunneling and engineering communication) is especially sharp.

The insulating materials for secondary protection that use now (on bitumen or cement base) are not enough preserve structures from destructive action of aggressive waters. Besides the most of this materials have negative action to environment. For decision of this problem it is suggested to make lining of tunnels with prefabricated blocks with basalt plastic finishing.

Basalt plastic lining (fig.1) is the special multilayer finishing composed of polymer binder, cut basalt filament, basalt plastic anchors for connection with concrete and intended for securing protection of inner surfaces of reinforced block basalt plastic s from possible mechanical, thermal, physical and chemical damages $[1,2]$.

*Corresponding author : olga.lyapidevskaya@inbox.ru 


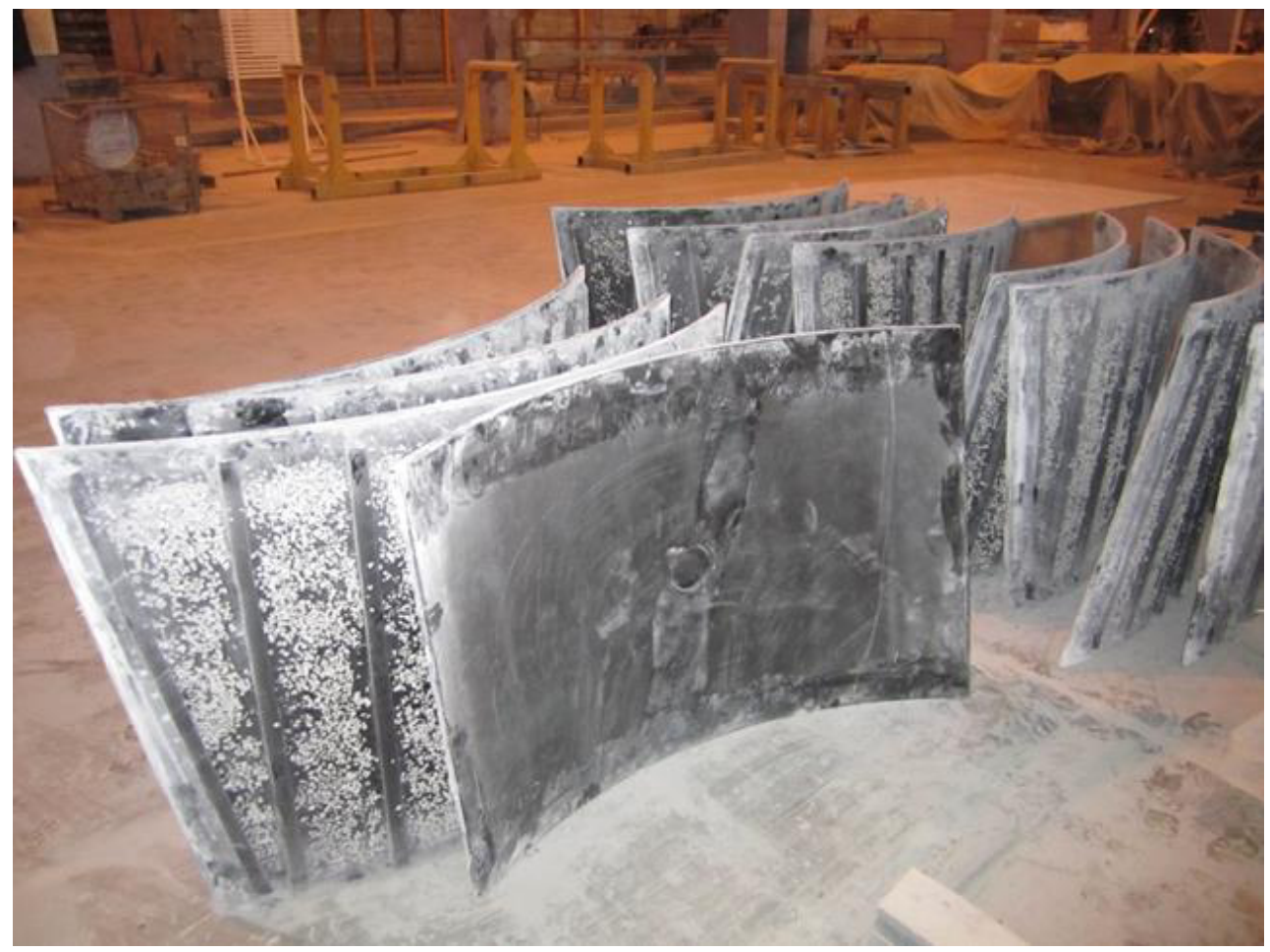

Fig. 1. Prefabricated elements with basalt plastic lining

The existing determination methods of filtration coefficient and assessment of water tightness of concrete don't take into account presence of joints between the separate elements of construction. However, namely these joints are the most vulnerable places for sewage water penetration into ground and ground waters creating geo ecological danger for environment.

In this work it is presented the method of estimation of filtration coefficient and assessment of water tightness basalt plastic lining of reinforced block that takes into account the influence of joints between blocks on water tightness the whole engineering collector.

The estimation of water tightness of basalt plastic lining of reinforced blocks is carried out on the base of works of G. M. Lomize and V. M. Nasberg [3, 4].

Calculation of water leakages from engineering collector constructed with reinforced blocks with basalt plastic lining and self-swelling rubber laying is carried out in accordance with formula (1):

$$
Q=\frac{1}{\frac{1}{K_{n o k}} \times \ln \frac{R_{n o k}}{R_{0}}+\frac{1}{K_{c r .0}} \times \frac{R}{R_{n o k}}+\frac{1}{K_{n}} \times \ln \frac{2 t}{R}}
$$

Where $\quad \mathrm{Q}$ - leakage of water from engineering collector, 1

$\mathrm{K}_{\text {nok }}$ - filtration coefficient of lining, $\mathrm{m} /$ day;

$\mathrm{K}_{\mathrm{cr} .0}$ - filtration coefficient of reinforced concrete blocks, $\mathrm{m} /$ day;

$\mathrm{K}_{\mathrm{n}}$ - filtration coefficient of rocks around collector, $\mathrm{m} /$ day;

$\mathrm{R}_{\text {nok }}$ - radius of outside zone of lining, $\mathrm{m}$;

$\mathrm{R}_{0}$ - radius of tunnel (inner), $\mathrm{m}$;

$\mathrm{R}$ - outside diameter of reinforced blocks, $\mathrm{m}$; 
$2 \mathrm{t}$ - radius of influence, $\mathrm{m}$; for tunnels with diameter $2-5 \mathrm{~m}$ it is recommended to take value $2 \mathrm{t}-200 \mathrm{~m}$;

$\mathrm{L}$ - length of engineering collector, $\mathrm{m}$;

$\mathrm{H}$ - pressure of water inside collector, $\mathrm{m}$

For the analogous engineering collector constructed with water tight lining made from cement mortar (secondary protection), the calculation of water leakages have made with the next formula (2)

$$
Q=\frac{2 \pi L\left(H_{e}-H_{0}\right)}{\frac{1}{K_{b}} \times \ln \frac{R_{b}}{R_{0}}+\frac{1}{K_{c r .0}} \times \frac{R}{R_{b . n}}+\frac{1}{K_{n}} \times \ln \frac{2 t}{R}}
$$

Where $\quad K_{b}-$ filtration coefficient of secondary lining, $m /$ day;

$\mathrm{R}_{\mathrm{b} . \mathrm{n}}-$ radius of outside secondary lining, $\mathrm{m}$;

$\mathrm{H}_{\mathrm{e}}-$ max. pressure of ground waters, $\mathrm{m}$ of water;

$\mathrm{H}_{0}$ - pressure of waters inside of engineering collector, $\mathrm{m}$

Analyzing presented dependences (1), (2) it's received that in general water tightness depends on filtration coefficient of engineering collector's structures and rocks around them.

Proceeded from foregoing the main problem of development new type of lining is to work out the reliable method of calculation filtration coefficient taking into account joints between blocks.

\section{Calculation of filtration coefficient of prefabricated reinforced blocks with basalt plastic lining}

This time the trust worthy information about filtration coefficient of polymer lining is absent. To determine the filtration coefficient it's used indirect characteristics such as quantity of water that flow through the collector, the inner specific surface of pores, vapor permeability [6-8]. For production of lining it is possible to use polymer compositions on the base of thermo reactive (for example, Polyester) resin and also PVC and polystyrene.

Table 1 contains comparative characteristics of listed materials.

Table 1. Characteristics of polymer materials

\begin{tabular}{|c|c|c|c|}
\hline Material & $\begin{array}{c}\text { Inner specific pores } \\
\text { surface, } \mathbf{~ m}^{\mathbf{2}} / \mathbf{m}^{\mathbf{3}}\end{array}$ & $\begin{array}{c}\text { Vapor permeability } \\
\mathbf{m g} /(\mathbf{m} * \mathbf{h} * \mathbf{P a})\end{array}$ & $\begin{array}{c}\text { Filtration } \\
\text { coefficient, } \\
\mathbf{m} / \mathbf{d a y}\end{array}$ \\
\hline $\begin{array}{c}\text { On the base of Polyester } \\
\text { resins }\end{array}$ & - & $\begin{array}{c}11,79 \cdot 10^{-5} \\
26,63 \cdot 10^{-5}\end{array}$ & $0,012 \cdot 10^{-7}$ \\
\hline PVC & $250-300$ & - & $<0,86 \cdot 10^{-7}$ \\
\hline Polystyrene & $60-700$ & - & $<0,86 \cdot 10^{-7}$ \\
\hline
\end{tabular}

Data presented in Table 1 were treated with using dependence (3) [9],

$$
K_{f}=(\alpha \times S-5,125) \times 10^{-5}
$$

Where $\mathrm{K} \_\mathrm{f}-$ filtration coefficient, $\mathrm{m} /$ day;

$\alpha$-Coefficient, equal 0,0004142 (is taken by processing experimental data);

$\mathrm{S}-$ Specific pores surface, $\mathrm{m}^{2} / \mathrm{m}^{3}$;

The material is considered as water tight at filtration coefficient $\mathrm{K}_{\mathrm{f}} \leq 5 \cdot 10^{-6} \mathrm{~m} /$ day [6]. 
Values of the filtration coefficient from Table 1 show that polymer lining is essentially water proof. The binder on the base of polyester resins has been choice so it has the least filtration coefficient.

As it was noted the existing methods of calculation of filtration coefficient don't take into account presence joints between blocks of engineering collectors that cause different errors at calculation.

It is supposed that in engineering collectors of reinforced concrete blocks with basalt plastic lining conjunction would be made with self-swelling rubbers and joints would be filled by epoxy thermo reactive resin.

In this case calculation of the filtration coefficient of reinforced concrete blocks with regard to the filtration coefficient and width of joints would be according formula (4).

$$
K_{c r .0}=\frac{B \times K_{b} \times l_{0}+K_{s t}\left[\left(B+l_{0}\right) \times \delta+\delta^{2}\right]}{\left(l_{0}+\delta\right)(B+\delta)}
$$

Where $\mathrm{K}_{\mathrm{cr} .0}-$ filtration coefficient of reinforced concrete blocks with regard to width of joints between blocks, $\mathrm{m} /$ day;

$\mathrm{K}_{\mathrm{b}}-$ Filtration coefficient of reinforced concrete blocks, $\mathrm{m} /$ day;

$\mathrm{K}_{\mathrm{st}}-$ Filtration coefficient of joints between blocks, $\mathrm{m} /$ day;

$\delta$ - Width of joints, $\mathrm{m}$;

B - Width of reinforced concrete block, m;

$1_{0}-$ size (thickness) of reinforced concrete block, $\mathrm{m}$.

Filtration coefficient of reinforced concrete blocks take as $\mathrm{K}_{\mathrm{b}}=0,069 \cdot 10^{-5} \mathrm{~m} /$ day [4].

Filtration coefficient of joints between blocks take as polymer lining $\mathrm{K}_{\mathrm{st}}=0,012 \cdot 10^{-7}$ $\mathrm{m} /$ day.

Filtration coefficients of reinforced concrete blocks depending on the width of joint are calculated according formula 4 and represented in Table 3 . The width of joints at construction of engineering collectors is from 0,005 up $0,03 \mathrm{~m}$.

Table 3. Filtration coefficients of reinforced concrete blocks depending on joint width

\begin{tabular}{|c|c|}
\hline Width of joint, $\mathbf{~ m}$ & $\begin{array}{c}\text { Filtration coefficients of reinforced concrete blocks } \\
\mathbf{K} \boldsymbol{\phi} \cdot \mathbf{1 0}^{-\mathbf{7}}, \mathbf{~} \mathbf{\text { day }}\end{array}$ \\
\hline 0,005 & 1,94 \\
\hline 0,010 & 2,01 \\
\hline 0,015 & 2,04 \\
\hline 0,020 & 2,09 \\
\hline 0,025 & 2,18 \\
\hline 0,030 & 2,29 \\
\hline
\end{tabular}

Analyzing the data of Table 3 it is possible to come to conclusion that collector constructed with blocks with basalt plastic lining is practically water tight at any acceptable width of joint. During tests of reinforced concrete blocks with applied hydraulic seal on cement base the filtration coefficient was $(0,81-1,78) \cdot 10^{-5} \mathrm{~m} /$ day that is much more than this index of concrete blocks with basalt polymer lining.

\section{Calculation of water leakage from engineering collector}

Calculation according formula 1 will be carried out with the use of the smallest filtration coefficient is equal $0,012 \cdot 10^{-7} \mathrm{~m} /$ day. Filtration coefficient of reinforced concrete blocks depending on the width of Diameter of engineering collector is $3,15 \mathrm{~m}$, inner diameter $2,75 \mathrm{~m}$, size (thickness) - 0, $20 \mathrm{~m}$. The ring of engineering collector with width $1 \mathrm{~m}$ consists of 6 blocks. Construction of engineering collectors mainly is conducted profundity and 
depth didn't exceed $20 \mathrm{~m}$. At the depth of $20 \mathrm{~m}$ ground waters create pressure $\mathrm{H}_{\mathrm{e}}$ up to 14,9 $\mathrm{m}$. To determine the resulting pressure $\mathrm{H}$ it would be considered the event of complete filling of engineering collector. In this case pressure of water inside collector will take $\mathrm{H}_{0}=$ $2,6 \mathrm{~m}$ of water [5].

Table 4. Filtering parameters, taken as the basis in estimation according formulas (1), (2)

\begin{tabular}{|c|c|c|c|c|c|c|}
\hline \multirow{2}{*}{$\begin{array}{c}\text { Leakages of water } \\
\text { from engineering } \\
\text { collector }\end{array}$} & \multicolumn{3}{|c|}{$\begin{array}{l}\text { Pressure, } m \text { of } \\
\text { water }\end{array}$} & \multicolumn{3}{|c|}{ Filtration coefficient, $\mathbf{m} /$ day } \\
\hline & $\mathbf{H}$ & $\mathbf{H}_{\mathbf{e}}$ & $\mathbf{H}_{0}$ & Lining & $\begin{array}{c}\text { Reinforced } \\
\text { blocks }\end{array}$ & $\begin{array}{l}\text { Secondary } \\
\text { protection }\end{array}$ \\
\hline $\begin{array}{l}\text { Reinforced blocks } \\
\text { with basalt plastic } \\
\text { lining }\end{array}$ & \multirow{2}{*}{12,3} & \multirow{2}{*}{14,9} & \multirow{2}{*}{2,6} & $0,012 \cdot 10^{-7}$ & $0,069 \cdot 10^{-5}$ & 1 \\
\hline $\begin{array}{l}\text { Reinforced blocks } \\
\text { with secondary } \\
\text { protection }\end{array}$ & & & & - & $2,1 \cdot 10^{-5}$ & $0,82 \cdot 10^{-5}$ \\
\hline
\end{tabular}

The results of estimation water leakages from engineering collector according formulas (1), (2) proceeding from filtering parameters presented in Table 4, are given in Table 5.

Table 5. Leakages of water from engineering collector

\begin{tabular}{|c|c|c|}
\hline \multirow{2}{*}{$\begin{array}{c}\text { Structures of engineering } \\
\text { collector }\end{array}$} & \multicolumn{2}{|c|}{$\begin{array}{c}\text { Leakages of water (Q) at } \\
\mathbf{L = 1 0} \text { m during } \mathbf{0 , 5} \text { hour }\end{array}$} \\
\cline { 2 - 3 } & $\mathbf{m}^{\mathbf{3}}$ & $\mathbf{l}$ \\
\hline $\begin{array}{c}\text { Reinforced blocks with basalt } \\
\text { plastic lining }\end{array}$ & 0,028 & 0,59 \\
\hline $\begin{array}{c}\text { Reinforced blocks with } \\
\text { secondary protection }\end{array}$ & 0,094 & 1,97 \\
\hline
\end{tabular}

\section{Conclusion}

The results of estimation (Table 5) have shown that hermetic nature of basalt plastic lining almost in 3,4 time exceeded secondary protection of engineering collectors $(0,59<1,971)$.

Thus, the application of basalt plastic lining for protection reinforced concrete blocks will increase geo ecological safety of city environment at the expense of contraction of failure at deterioration of water tightness of engineering collectors and contamination of soil and ground waters by sewage.

\section{References}

1. O.B. Lyapidevskaya, A.K. Sherstnev, MATEC Web of Conferences, 86, 03005 (2016)

2. O.B. Lyapidevskaya, A.K. Sherstnev, Procedia Engineering, 153, 434-438 (2016)

3. G.M. Lomize. Filtration in cracked rocks (1951)

4. V. M. Nasberg Estimation of filtration of geotechnical tunnels («Izvestia VNIIG», T. 58, Gosenergoizdat, 1958 )

5. SP 129.13330.2011 External networks and constructions of water supply and Sewerag

6. Handbook for the processing of materials of engineering-geological surveys. - M: THE GIFT / VODGEO, (2005)

7. SP 74.13330.2011 Heat networks 
8. A.A. Shilin, M.V. Zaytsev, I.A. Zolotarev, O.B. Lyapidevskaya, Waterproofing of underground and deepened constructions during building and repair (2003)

9. E.Y. Kulikova, Filtration reliability of city underground structures. (Peace of mountain book 2007)

10. GOST 12730.5-84 Concretes. Methods for determination of water tightness. 